\title{
Measuring and simulating maize (Zea mays L.) yield responses to reduced tillage and mulching under semi-arid conditions
}

\author{
Walter Mupangwa ${ }^{1,2, a^{*}}$, John Dimes ${ }^{1}$, Sue $_{\text {Walker }}{ }^{2}$, Stephen Twomlow ${ }^{1, b}$ \\ ${ }^{1}$ CRISAT, Matopos Research Station, Bulawayo, Zimbabwe; *Corresponding Author: w.mupangwa@cgiar.org, \\ mupangwa@yahoo.com \\ ${ }^{2}$ Department of Soil, Crop and Climate Sciences, University of Free State, Bloemfontein, South Africa; \\ ${ }^{a}$ Present address: CIMMYT Regional Office, Mount Pleasant, Harare, Zimbabwe; \\ ${ }^{\mathrm{b}}$ Present address: United Nations Environment Programme, Nairobi, Kenya.
}

Received 26 April 2011; revised 23 June 2011; accepted 21 July 2011.

\begin{abstract}
Rainfed smallholder agriculture in semi-arid environments of sub-Saharan Africa faces many challenges. Productivity of the smallholder agricultural systems has been on the decline in recent years. Conservation agriculture practices have a potential of steering the smallholder agricultural systems of sub-Saharan Africa to greater and more sustainable levels. This study was designed to calibrate the APSIM model so that it could be used as a tool for understanding the long term impact of conservation agriculture techniques (mulching, tine ripping and planting basins) on the productivity of smallholder systems under semi-arid conditions. The APSIM model predicted reasonably well the seasonal and mulching effects on maize production on sand and clay soils. Under these semi-arid conditions the use of $10 \mathrm{~kg} \cdot \mathrm{N} \cdot \mathrm{ha}^{-1}$ is preferable under both conventional and basin tillage systems. Planting basins offer a better chance of getting maize grain yield than the conventional system in southern Zimbabwe at $\mathbf{N}$ quantities ranging from $0 \mathrm{~kg} \cdot \mathrm{ha}^{-1}$ to $52 \mathrm{~kg} \cdot \mathrm{ha}^{-1}$. This modelling exercise suggested that smallholder farmers are still prone to complete crop failure in some years despite the use of available conservation agriculture systems.
\end{abstract}

Keywords: Nitrogen; Modelling; Planting Basins; Semi-Arid; Variable Rainfall; Zimbabwe

\section{INTRODUCTION}

Conservation agriculture has the potential to steer the productivity of smallholder systems to greater levels.
The advent of conservation agriculture tillage techniques such as planting basins brought a ray of hope to smallholder farmers in the semi-arid regions of sub-Saharan Africa [1]. The planting basin tillage system being promoted throughout Zimbabwe enables farmers to prepare land early, spread the limited farm labour and plant on time with respect to the effective planting rain $[2,3]$. The planting basins dug by hand in a grid of $0.9 \mathrm{~m} \times 0.6 \mathrm{~m}$ spacing harvest rainwater and reduce surface runoff from cropping fields [4], increase crop yields substantially [2, 5].

Although planting basins have been in use on smallholder farms for less than 10 growing seasons, the use of simulation modeling can help understand the long-term impact of the tillage system under semi-arid conditions. The Agricultural Production Simulator Model (APSIM), a deterministic and process based model, has been used for simulating crop production in smallholder cropping systems. The APSIM model has performed well in predicting crop production and its interaction with climate, soil and management factors [6]. In smallholder farming systems, APSIM has been used with success to simulate nitrogen $(\mathrm{N})$ dynamics of manure inputs [7], maize response to $\mathrm{N}$ [8], water use efficiency [9], and $\mathrm{N}$ and water dynamics in cereal-legume rotations [10]. However, no description of the effects reduced tillage systems (ripper tine and planting basin tillage systems) and mulch, which are the corner stone of conservation agriculture, on crop yields and soil water dynamics has been reported in any of the previous studies.

This study was designed to evaluate the capability of APSIM cropping systems model (version 6.0) to simulate maize (Zea mays L.) yield responses to different rainfall seasons, mulch levels and three tillage systems on two soil types, Soil 1 was a granitic sand (Eutric arenosol) and Soil 2 a clay (Chromic-Leptic cambisol) 
[11]. Data obtained from on-station experiments $[5,12]$ were used to verify the model performance. The validated APSIM model was then used to assess the long term interaction effects of $\mathrm{N}$ and two tillage systems, conventional ploughing and planting basins, on maize yield and selected components of the soil water balance for a granitic sand soil under the semi-arid conditions of southern Zimbabwe. The specific objectives were 1) to evaluate APSIM capability in predicting the seasonal and mulching effects on maize grain and total biomass yields and 2) to use the validated APSIM model to assess the long term interaction effects of $\mathrm{N}$ fertilizer, and conventional and planting basin tillage systems on maize yields.

\section{MATERIALS AND METHODS}

\subsection{Experimental Sites}

The experiment was run at the International Crops Research Institute for Semi-Arid Tropics (ICRISAT), Matopos Research Station from 2004/05 through to the $2007 / 08$ cropping seasons on two soil types, a clay and a granitic sand. The clay soil is located at the main Matopos experimental site $\left(28^{\circ} 30^{\prime} \mathrm{E}, 20^{\circ} 23^{\prime} \mathrm{S}\right.$, and $1344 \mathrm{~m}$ above sea level) and is classified as a shallow siallitic soil (4E.1) and Chromic-Leptic Cambisol according to the Zimbabwean and FAO systems respectively [11]. The internal drainage of Matopos clay soil indicates saturation for short periods during the rainy season and external drainage is characterized by slow runoff [11]. The granitic sand is located at the Lucydale experimental site $\left(28^{\circ} 24^{\prime} \mathrm{E}, 20^{\circ} 25^{\prime} \mathrm{S}\right.$, and $1378 \mathrm{~m}$ above sea level) and is classified in the Zimbabwean system as moderately deep to deep well-drained fersiallitic soil (5G.2). This is classified as Eutric Arenosol [13]. Internal drainage of Lucydale sand is rapid to very rapid and external drainage is characterized by slow runoff [11]. The chemical and physical properties of the two soil types have been described by [5]. Matopos Research Station receives annual rainfall ranging between 450 and $650 \mathrm{~mm}$ with a long-term average rainfall $573 \mathrm{~mm}$.

\subsection{Summary of the Field Experiment}

The experiment was set up with a factorial treatment structure consisting of three tillage methods (conventional ploughing, ripping and planting basins) and seven rates of mulch cover $\left(0,0.5,1,2,4,8\right.$ and $\left.10 \mathrm{t} \cdot \mathrm{ha}^{-1}\right)$. The treatments were arranged in a split-plot design with three replications at each field location. The main plot factor was tillage $(63 \mathrm{~m} \times 6 \mathrm{~m})$ and seven mulch levels were randomly allocated in sub-plots $(8 \mathrm{~m} \times 6 \mathrm{~m})$ on each tillage treatment. Basins were dug at $0.9 \mathrm{~m} \times 0.6 \mathrm{~m}$ spacing using a hand hoe and each basin measured 0.15 $\mathrm{m}$ (length) $\times 0.15 \mathrm{~m}$ (width) $\times 0.15 \mathrm{~m}$ (depth). Rip lines were opened at $0.9 \mathrm{~m}$ inter-row spacing using a commercially available ripper tine (Zim Plow type) attached to the beam of a donkey-drawn mouldboard plough (VS 100). The ripping depth achieved on both soils, with a single pass of the implement, varied between 0.15 and $0.18 \mathrm{~m}$. Cattle manure ( $8 \%$ organic carbon, $0.32 \% \mathrm{~N})$ was applied in October each year at a rate of $3 \mathrm{t} \cdot \mathrm{ha}^{-1}$ in all plots as basal soil fertility amendment. Conventional ploughing was done soon after the first effective rain (30 to $50 \mathrm{~mm}$ ) in December each year using a donkey-drawn VS 100 mouldboard plough. Ammonium nitrate $(34.5 \%$ $\mathrm{N})$ was applied to all plots at $20 \mathrm{~kg} \cdot \mathrm{N} \cdot \mathrm{ha}^{-1}$ as topdressing six weeks after planting.

\subsection{Set up of the Model}

The simulation was run from 1 October 2004 to 30 June 2008 and the model was reset every 1 July to initial soil nitrogen and water content. Soil parameters used for calibrating the APSIM model are given in Tables $\mathbf{1}$ and 2. As the experiment had a new field established in each season at the Matopos site, the plant available water capacity (PAWC) for 2004/05 field was $116 \mathrm{~mm}, 84 \mathrm{~mm}$ for 2005/06, $61 \mathrm{~mm}$ for 2006/07 and $84 \mathrm{~mm}$ for 2007/08 in the $0-0.85 \mathrm{~m}$ soil profile. The drained upper limit (DUL), saturation (SAT) and lower limit (LL) were derived from soil water measurements made in the planting basins with no mulch cover. For Lucydale site the same field was used for the two seasons (2004/05 and 2005/06) and the PAWC in the $0-0.70 \mathrm{~m}$ soil profile was $54 \mathrm{~mm}$.

Table 1. Soil chemical and physical properties of the clay soil used for Matopos Research Station experimental site (adapted from ICRISAT unpublished data).

\begin{tabular}{|c|c|c|c|c|c|c|}
\hline Depth (cm) & $\mathbf{p H}$ & $\mathrm{NO}_{3}-\mathrm{N}$ (ppm) & $\begin{array}{c}\text { Organic carbon } \\
(\%)\end{array}$ & $\begin{array}{c}\text { Bulk density } \\
\left(\mathrm{g} \cdot \mathrm{cm}^{-3}\right)\end{array}$ & DUL (mm/mm) & LL (mm/mm) \\
\hline $0-15$ & 6.0 & 6.50 & 1.20 & 1.4 & 0.20 & 0.10 \\
\hline $15-25$ & 6.0 & 2.10 & 1.00 & 1.4 & 0.24 & 0.10 \\
\hline $35-45$ & 6.0 & 1.70 & 0.83 & 1.4 & 0.27 & 0.16 \\
\hline $45-55$ & 6.0 & 1.70 & 0.58 & 1.4 & 0.29 & 0.20 \\
\hline $55-65$ & 6.0 & 1.70 & 0.54 & 1.4 & 0.29 & 0.21 \\
\hline $65-75$ & 6.0 & 1.70 & 0.54 & 1.4 & 0.30 & 0.23 \\
\hline $75-85$ & 6.0 & 1.70 & 0.50 & 1.4 & 0.31 & 0.25 \\
\hline
\end{tabular}


Table 2. Soil chemical and physical properties of the sand soil used for Lucydale experimental site (adapted from Masikati, 2006 and Ncube et al., 2009).

\begin{tabular}{|c|c|c|c|c|c|c|}
\hline Depth (cm) & $\mathbf{p H}$ & $\mathrm{NO}_{3}-\mathrm{N}$ (ppm) & $\begin{array}{c}\text { Organic carbon } \\
(\%)\end{array}$ & $\begin{array}{c}\text { Bulk density } \\
\left(\mathrm{g} / \mathrm{cm}^{3}\right)\end{array}$ & DUL (mm/mm) & $\mathbf{L L}(\mathbf{m m} / \mathbf{m m})$ \\
\hline $0-20$ & 6.3 & 1.41 & 0.8 & 1.66 & 0.15 & 0.05 \\
\hline $20-30$ & 6.3 & 1.41 & 0.7 & 1.65 & 0.22 & 0.13 \\
\hline $40-50$ & 6.9 & 0.31 & 0.7 & 1.55 & 0.34 & 0.27 \\
\hline $50-60$ & 6.9 & 0.31 & 0.7 & 1.51 & 0.37 & 0.32 \\
\hline $60-70$ & 6.3 & 0.24 & 0.6 & 1.34 & 0.41 & 0.36 \\
\hline
\end{tabular}

Table 3. Dates for field activities carried out at Matopos Research Station during the four seasons of experimentation.

\begin{tabular}{|c|c|c|c|c|c|}
\hline Season & Tillage method & Mulch application & Manure application & Sowing date & Topdressing date \\
\hline \multirow[t]{3}{*}{$2004 / 05$} & Plough & $10 / 11 / 2004$ & $12 / 12 / 2004$ & $13 / 12 / 2004$ & $21 / 1 / 2005$ \\
\hline & Ripper & $10 / 11 / 2004$ & $26 / 10 / 2004$ & $13 / 12 / 2004$ & $21 / 1 / 2005$ \\
\hline & Basins & $10 / 11 / 2004$ & $20 / 10 / 2004$ & $13 / 12 / 2005$ & $21 / 1 / 2005$ \\
\hline \multirow[t]{3}{*}{$2005 / 06$} & Plough & $15 / 9 / 2005$ & $13 / 12 / 2005$ & $13 / 12 / 2005$ & $24 / 1 / 2006$ \\
\hline & Ripper & $15 / 9 / 2005$ & $18 / 9 / 2005$ & $13 / 12 / 2005$ & $24 / 1 / 2006$ \\
\hline & Basins & $15 / 9 / 2005$ & $17 / 9 / 2005$ & $13 / 12 / 2005$ & $24 / 1 / 2006$ \\
\hline \multirow[t]{3}{*}{$2006 / 07$} & Plough & $28 / 7 / 2006$ & $7 / 12 / 2006$ & $8 / 12 / 2006$ & $2 / 1 / 2007$ \\
\hline & Ripper & $28 / 7 / 2006$ & $30 / 8 / 2006$ & $21 / 11 / 2006$ & $2 / 1 / 2007$ \\
\hline & Basins & $28 / 7 / 2006$ & $28 / 8 / 2006$ & $21 / 11 / 2006$ & $2 / 1 / 2007$ \\
\hline \multirow[t]{3}{*}{$2007 / 08$} & Plough & $25 / 7 / 2007$ & $12 / 12 / 2007$ & $12 / 12 / 2007$ & $10 / 1 / 2008$ \\
\hline & Ripper & $25 / 7 / 2007$ & $5 / 8 / 2007$ & $12 / 12 / 2007$ & $10 / 1 / 2008$ \\
\hline & Basins & $25 / 7 / 2007$ & $27 / 9 / 2007$ & $12 / 12 / 2008$ & $10 / 1 / 2008$ \\
\hline
\end{tabular}

Table 4. Dates for field activities carried out at Lucydale experimental site during the two seasons of experimentation.

\begin{tabular}{ccccc}
\hline Season & Tillage method & Mulch application & Manure application & Sowing \\
\hline $2004 / 05$ & Plough & $17 / 10 / 2004$ & $13 / 12 / 2004$ & $14 / 12 / 2004$ \\
& Ripper & $17 / 10 / 2004$ & $25 / 10 / 2004$ & $14 / 12 / 2004$ \\
$2005 / 06$ & Basins & $17 / 10 / 2004$ & $26 / 10 / 2004$ & $14 / 12 / 2004$ \\
& Plough & $*$ & $12 / 12 / 2005$ & $13 / 12 / 2005$ \\
& Ripper & $*$ & $8 / 9 / 2005$ & $13 / 12 / 2005$ \\
& Basins & $*$ & $14 / 9 / 2005$ & $13 / 12 / 2005$ \\
\hline
\end{tabular}

*No fresh mulch was applied

The Lucydale soil parameters were adapted from [14] and [10] (Table 2). The fields used by [14] and [10] were adjacent to our experimental field used in the 2004/ 05 and 2005/06 growing seasons.

Total soil $\mathrm{N}$ for Matopos clay soil was set at 25 $\mathrm{kg} \cdot \mathrm{ha}^{-1}\left(20 \mathrm{~kg} \mathrm{NO}-\mathrm{NO}_{3}^{-}\right.$and $\left.5 \mathrm{~kg} \mathrm{NH} \mathrm{NH}_{4}^{+}\right)$. Soil $\mathrm{N}$ for the Lucydale sandy soil was adapted from Ncube et al. (2009) and set at $10 \mathrm{~kg} \cdot \mathrm{ha}^{-1}\left(5 \mathrm{~kg} \mathrm{NO} \mathrm{NO}_{3}^{-}\right.$and $5 \mathrm{~kg}$ $\mathrm{NH}_{4}^{+}$). Soil water was reset to zero on the first of July each year while $\mathrm{N}$ was reset to $25 \mathrm{~kg} \cdot \mathrm{ha}^{-1}$ on the same date. Soil organic matter was not reset every first of July to allow for accumulation of organic matter in the soil. It was assumed that the $3 \mathrm{t} \cdot \mathrm{ha}^{-1}$ of manure used in our experiment supplied $9.6 \mathrm{~kg} \cdot \mathrm{N} \cdot \mathrm{ha}^{-1}$. Runoff curve number for bare soil across the three tillage treatments was set at 80 because the tillage techniques created surface roughness of varying degrees. For the conventional plough and ripper tillage systems the curve number was adjusted downwards by 10 units which were lost after $50 \mathrm{~mm}$ of rainfall, so it then reverted to 80 . For the planting basins the curve number was adjusted downwards by 20 units which were lost after $250 \mathrm{~mm}$ of rainfall was received.
The C:N ratio of mulching material was set at $60(0.67 \%$ $\mathrm{N})$ and a $10 \%$ incorporation of the mulching material in the $\mathrm{CP}$ system was assumed. For the planting basins and ripper tillage systems a $0 \%$ incorporation of the mulching material was assumed. The C:N ratio of all soils was set at 0.15 . The first and second stage evaporation coefficients were set at 3 and $6 \mathrm{~mm} \cdot \mathrm{day}^{-0.5}$ for the heavy textured Matopos soil, and 1 and $6 \mathrm{~mm} \cdot \mathrm{day}^{-0.5}$ for the light textured Lucydale soil.

Daily rainfall, temperature and radiation data were collected from Matopos Research Station weather station which is located $3 \mathrm{~km}$ from Matopos experimental site and up to $10 \mathrm{~km}$ from the Lucydale site. The climate record used for APSIM calibration stretched from 1 October 2004 to 30 June 2008. Experimental management in the model was according to the field experimental procedures [12]. Sowing, manure application and topdressing dates for Matopos and Lucydale experimental sites are given in Tables 3 and $\mathbf{4}$. For the conventional plough treatment at Lucydale manure was applied a day before sowing in each season, sowing being 14 and 13 December for 2004/05 and 2005/06 seasons according to 
the rain received. For planting basins treatment at Lucydale manure was applied on 26 October 2004 and 14 September 2005 for 2004/05 and 2005/06 growing seasons. A sowing depth of $50 \mathrm{~mm}$ was used in the simulation for each tillage system. Average plant stands of 1.8 and 3.1 plants per $\mathrm{m}^{2}$ were used for Lucydale in 2004/05 and 2005/06 seasons. For Matopos a plant density of 3.0 plants per $\mathrm{m}^{2}$ was used for the four growing seasons. All plots were kept weed free during period of experimentation. The APSIM model simulated maize yield and soil water balance until the crop was mature.

APSIM crop module contains a description of the short season hybrid variety SC401 used in Zimbabwe. In our experiment a short seasoned hybrid variety SC403 was planted at Matopos in all seasons and at Lucydale in $2005 / 06$. An open pollinated variety ZM421 was planted at Lucydale in 2004/05 season because there was a maize breeding experiment close to our research field. The three varieties are drought tolerant, have similar duration and are recommended for semi-arid areas of Zimbabwe. Hence APSIM crop parameters for SC401 were selected to describe both SC403 and ZM421 used in the study.

\subsection{Long Term Simulation}

The long term simulation was run using soil properties of the Lucydale granitic sandy soil. The 69 year climate record (1939-2008) derived from Matopos Research Station weather station was used in the long term simulation. The following scenarios were used in long term simulation:

- Conventional ploughing plus four $\mathrm{N}$ rates $(0,10,20$ and $52 \mathrm{~kg} \cdot \mathrm{ha}^{-1}$ )

- Planting basins plus four $\mathrm{N}$ rates $(0,10,20$ and 52 $\mathrm{kg} \cdot \mathrm{ha}^{-1}$ )

The $\mathrm{N}$ rates of 0,10 and $20 \mathrm{~kg} \cdot \mathrm{ha}^{-1}$ were similar to $\mathrm{N}$ levels used in the on-farm experiments conducted in Gwanda and Insiza districts of southern Zimbabwe during the 2005/06, 2006/07 and 2007/08 growing seasons. The $52 \mathrm{~kg} \cdot \mathrm{N} \cdot \mathrm{ha}^{-1}$ is the national recommendation for smallholder cropping systems of Zimbabwe [15] so it was included to provide a comparison with what may be considered as providing optimal yields under semi-arid conditions. Topdressing with ammonium nitrate $(34.5 \%$ $\mathrm{N})$ was done at 40 days after sowing in both tillage systems. A sowing window stretching from 20 November to 31 December and a plant density of 3.0 plants per $\mathrm{m}^{2}$ were used for the 69 year simulation.

\subsection{Reporting Frequency}

For the on-station experiments the model was set to report selected variables on a daily time step. The re- ported variables for the on-station experiments were total biomass and grain yield, soil water content in the 0 - $0.25 \mathrm{~m}$ layer, surface runoff and deep drainage. Total biomass and grain yields were reported at $0 \%$ moisture content and are compared to observed yields at this moisture content. In the long term simulation the model was set up to report variables at harvest stage of the maize crop. In the long term simulation the reported variables were grain yield, pre-sowing and in-crop surface runoff, and in-crop deep drainage.

The root mean square deviation (RMSD) and modeling efficiency (ME) values were calculated for comparison of observed and predicted data. The RMSD was calculated as follows:

$$
\operatorname{RMSD}=\left[1 / n \sum\left(x_{i}-y_{i}\right)^{2}\right]^{0.5}
$$

where $x_{i}$ is the observed yield or soil water content, $y_{i}$ is the predicted yield or soil water content and $n$ is the number of observations.

Modeling Efficiency (ME) was calculated as follows:

$$
\mathrm{ME}=\frac{\left[\sum_{i=1}^{n}\left(O_{i}-\bar{O}\right)^{2}-\sum_{i=1}^{n}\left(P_{i}-O_{i}\right)^{2}\right]}{\sum_{i=1}^{n}\left(O_{i}-\bar{O}\right)^{2}}
$$

where $P i$ and $O$ are predicted and observed values respectively, $\bar{O}$ is observed mean value [15].

\section{RESULTS AND DISCUSSION}

The total seasonal rainfall was $320 \mathrm{~mm}$ for 2004/05, $915 \mathrm{~mm}$ for $2005 / 06,467 \mathrm{~mm}$ for $2006 / 07$ and $364 \mathrm{~mm}$ for $2007 / 08$. The predicted seasonal effects on maize grain and biomass production at Matopos are shown in Figures 1 and 2. Seasonal effects on grain $(\mathrm{ME}=0.86)$ and biomass $(\mathrm{ME}=0.84)$ production were simulated reasonably well for the four growing seasons with different rainfall patterns at Matopos. The model gave a good prediction of grain yield in 2004/05 which was a below average season in terms of rainfall received (320 $\mathrm{mm})$. For the other below average rainfall seasons, 2006/ 07 and 2007/08, the predicted yields did not really match the observed values.

The predicted mulching effect on grain and biomass yields in the four seasons at Matopos is also shown in Figures 1 and 2. For the 2004/05, 2005/06 and 2006/07 seasons the model over predicted grain yield at 0 and 0.5 $\mathrm{t} \cdot \mathrm{ha}^{-1}$ mulch cover (Figure 1). The model below predicted grain production at 8 and $10 \mathrm{t} \cdot \mathrm{ha}^{-1}$ mulch cover in the same seasons. In the 2007/08 season the model under predicted grain production at low mulch levels $\left(<4 \mathrm{t} \cdot \mathrm{ha}^{-1}\right)$ while over predicting it at 8 and $10 \mathrm{t} \cdot \mathrm{ha}^{-1}$ (Figure 1). For the wetter 2005/06 season the model under predicted grain production and indicated a decrease in yield 


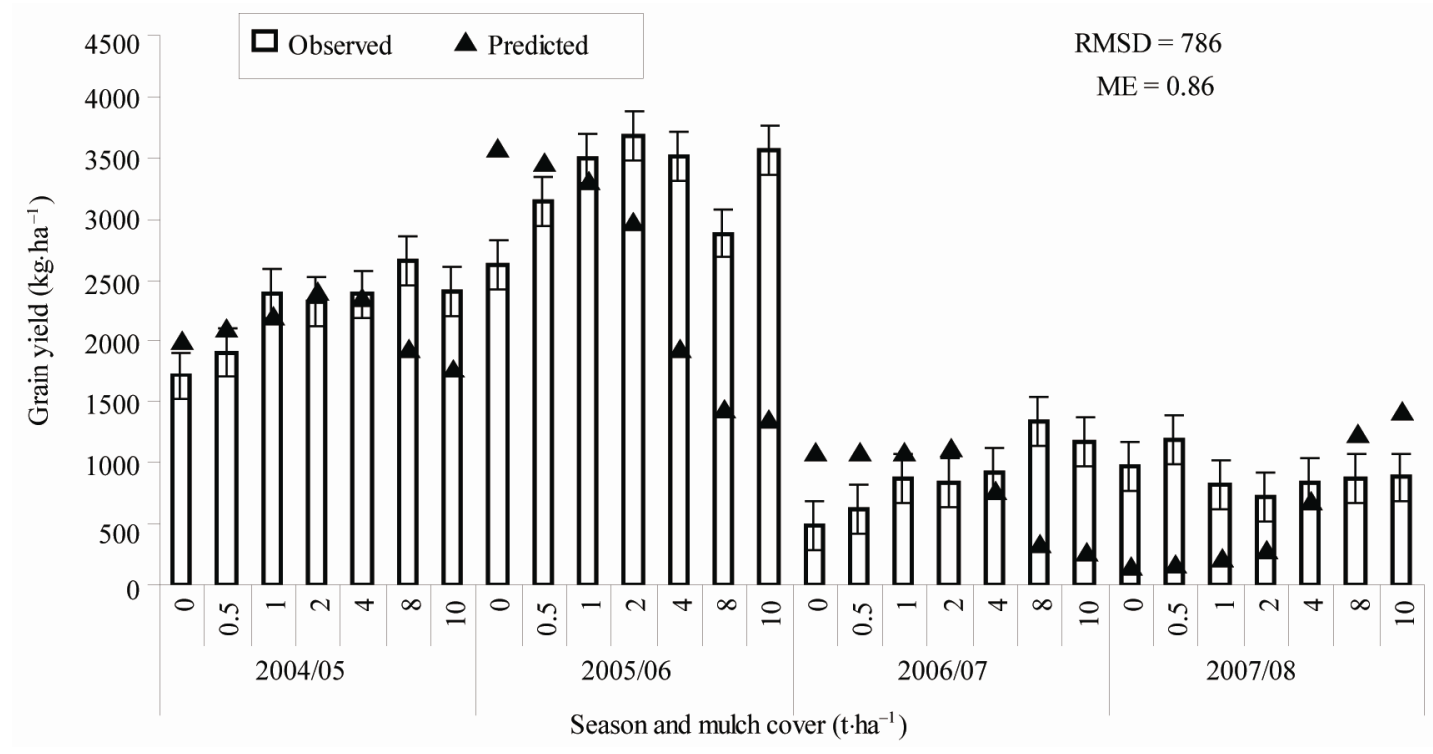

Figure 1. Observed and predicted grain yield from different mulch levels over four growing seasons at Matopos Research Station. Error bars stand for standard error of means for the different mulch levels in each season across three replications.

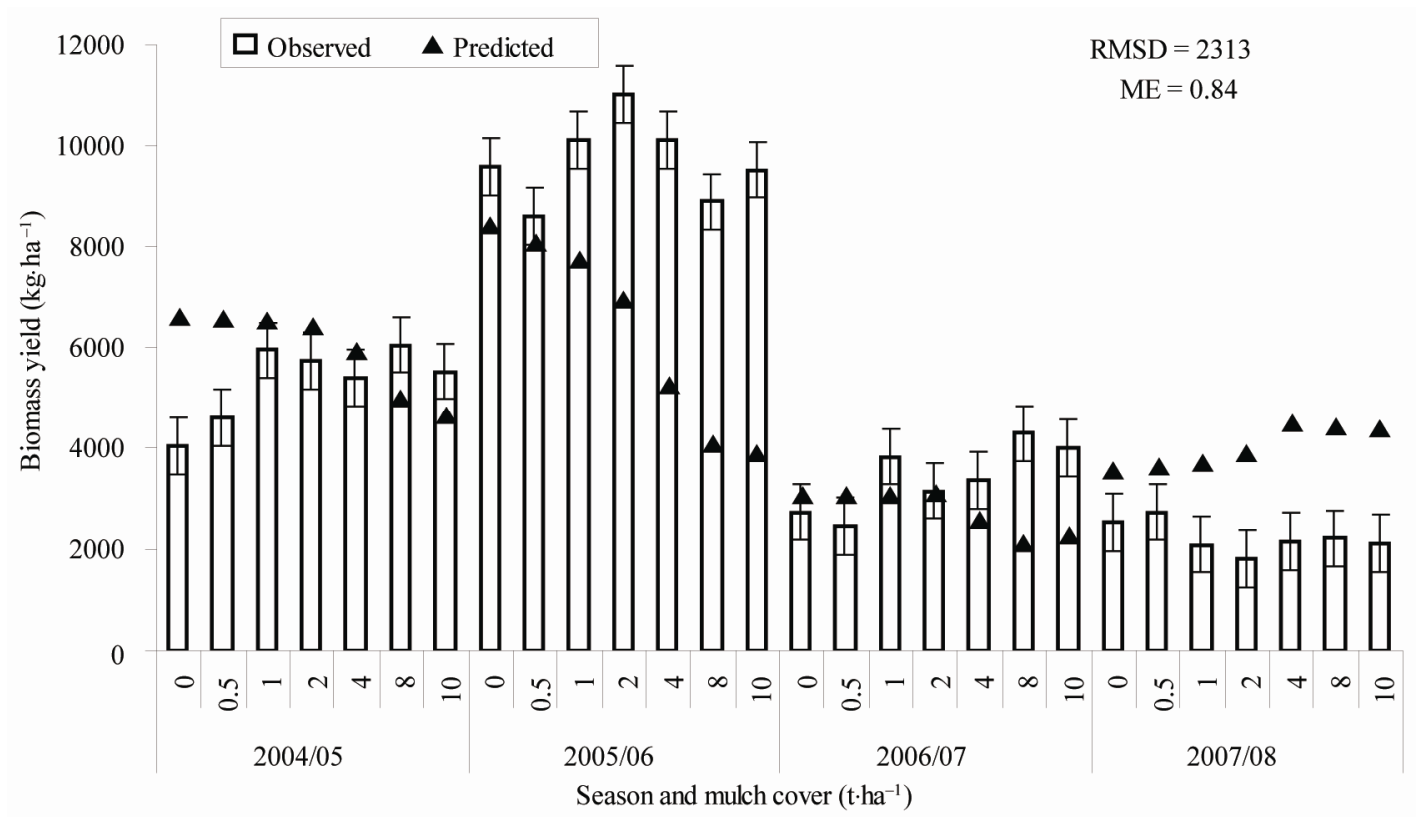

Figure 2. Observed and predicted total biomass yields from different mulch levels over four growing seasons at Matopos Research Station. Error bars stand for standard error of means for the different mulch levels in each season across three replications.

with increase in mulch cover on the clay soil (Figure 1). This is in contrast to what was observed in the field experiment at Matopos [5,12]. The modeling results suggest that mulch cover could have promoted immobilization of $\mathrm{N}$ given the better supply of soil water during the 2005/06 season. To be able to decompose the maize residue mulch soil micro-organisms need energy and therefore out-compete the maize plants in extracting soil $\mathrm{N}$.
The $29.6 \mathrm{~kg} \cdot \mathrm{N} \cdot \mathrm{ha}^{-1}$ was probably not enough to meet microbial and crop requirements thereby resulting in inadequate $\mathrm{N}$ supply to the maize crop and thus a lower predicted yield at higher mulch levels. Yellowing of maize foliage indicating $\mathrm{N}$ deficiency was observed at 8 and $10 \mathrm{t}^{\mathrm{h}} \mathrm{h}^{-1}$ mulch level particularly at the Matopos experimental site resulting in lower yield being achieved at $8 \mathrm{t}^{\circ} \mathrm{ha}^{-1}$ mulch (Figure 1). 
The model under predicted maize biomass production at higher mulch levels during the relatively wet 2005/06 growing season at Matopos (Figure 2). In the 2007/08 season the model predicted an increase in biomass yield with higher mulch cover at Matopos (Figure 2). The model is probably indicating soil water benefits derived from mulching in 2007/08 season that was characterized by an abrupt end of rain in January 2008. The model is indicating that higher mulch cover conserve soil water allowing the maize crop to reach maturity. However, observed maize yield data did not show any significant influence of mulch cover on either the total biomass or grain yields in the 2007/08 season. The lack of yield response to mulching in the 2007/08 season could be attributed to the fact that some experimental plots were waterlogged between the end of December 2007 and mid-January 2008. This was observed at higher mulch levels $\left(>2 t \cdot h a^{-1}\right)$ particularly in the planting basin and ripper tillage systems. Waterlogging promotes poor soil aeration and uptake of nutrients by plant roots [16]. At the Lucydale experimental site, the model predicted no significant grain yield responses to freshly applied mulch in 2004/05 and residual mulch cover in 2005/06 seasons (Figure 3). Lack of grain yield responses to freshly applied and residual mulch in 2004/05 and $2005 / 06$ is consistent with observed results. Field observations made in all seasons showed that maize residue applied as mulch decomposed quite fast particularly in a season with a lot of rain like 2005/06. At the end of growing season (April/May) there was hardly any maize residue left at the surface in the experimental plots espe- cially where $0.5,1$ and 2 thha ${ }^{-1}$ had been applied. An estimated $30 \%-40 \%$ mulch cover would be remaining in the 8 and $10 \mathrm{t}^{\mathrm{a}} \mathrm{ha}^{-1}$ treatments. Degradation of the mulching material could have been driven by termites which, unlike soil micro-organisms, do not need to take up $\mathrm{N}$ from the soil in order to degrade the plant residues [17]. Maize residue, with a C:N ratio averaging 52 [18], decomposes fast when conditions of drivers of decomposition such as rainfall, temperature and soil microorganisms are ideal [19]. The APSIM model predicted a decrease in biomass yield with increase in mulch cover in the 2005/06 growing season (Figure 4). This suggests a suppression of biomass production owing to $\mathrm{N}$ immobilization as some maize residues carried over from the 2004/05 season were still being decomposed during the 2005/06 growing season.

The basin system has higher chances of giving grain yield than the conventional system regardless of $\mathrm{N}$ level used in semi-arid environment of southern Zimbabwe (Figure 5). There is a $48 \%$ chance of getting grain yield without $\mathrm{N}$ fertilizer in the basin system compared with $31 \%$ in the conventional system. At $10 \mathrm{~kg} \cdot \mathrm{N} \cdot \mathrm{ha}^{-1}$ the chances of getting higher grain yield from the basin system than the conventional system increases to $52 \%$. The predicted grain yield suggests that the use of 10 $\mathrm{kg} \cdot \mathrm{N} \cdot \mathrm{ha}^{-1}$ in both the conventional and planting basin systems is a good entry point for improving productivity in the cereal dominated semi-arid cropping systems of Zimbabwe (Figure 5). This confirms earlier results from the wide scale promotion of inorganic fertilizer which was con ducted in semi-arid districts of Zimbabwe [20].

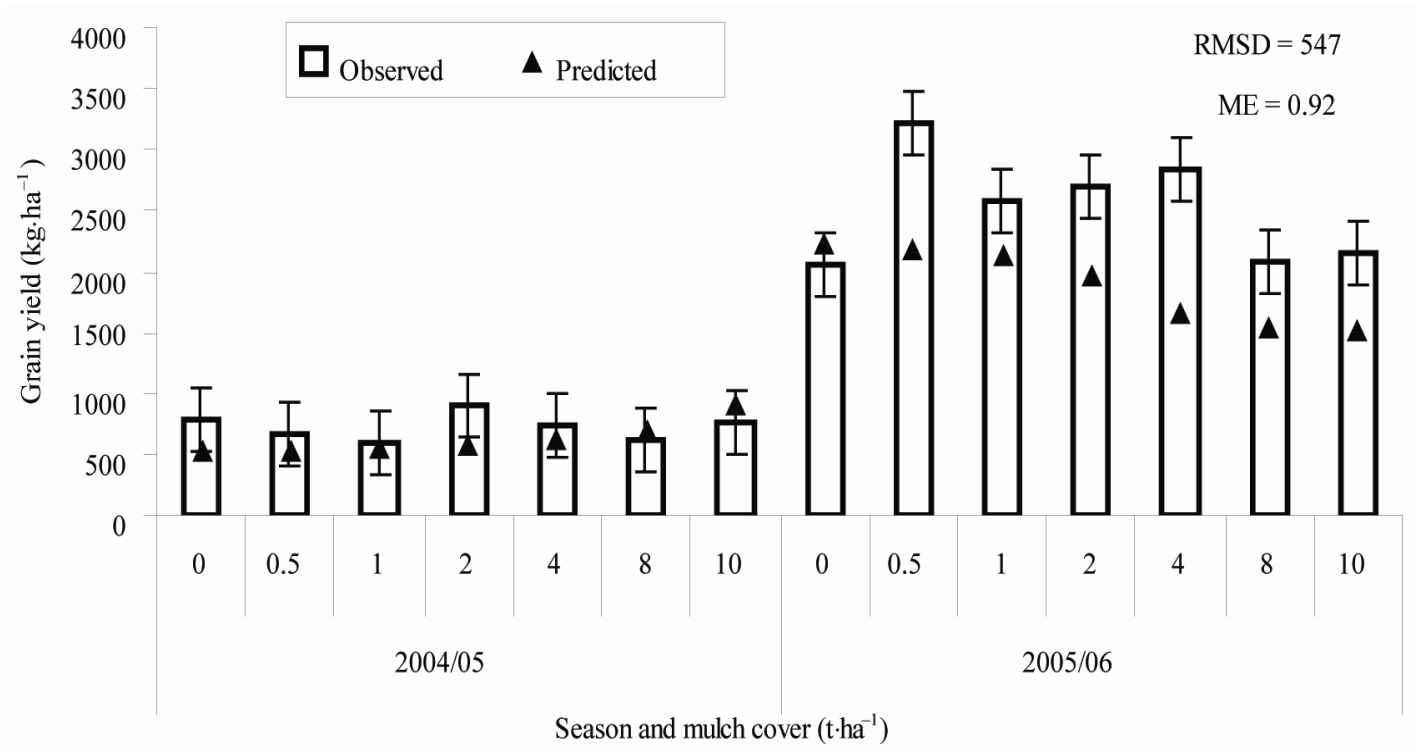

Figure 3. Observed and predicted grain yields for different mulch levels on a sand soil over two growing seasons at Lucydale experimental site. Error bars stand for standard error of means for the different mulch levels in each season across three replications. 


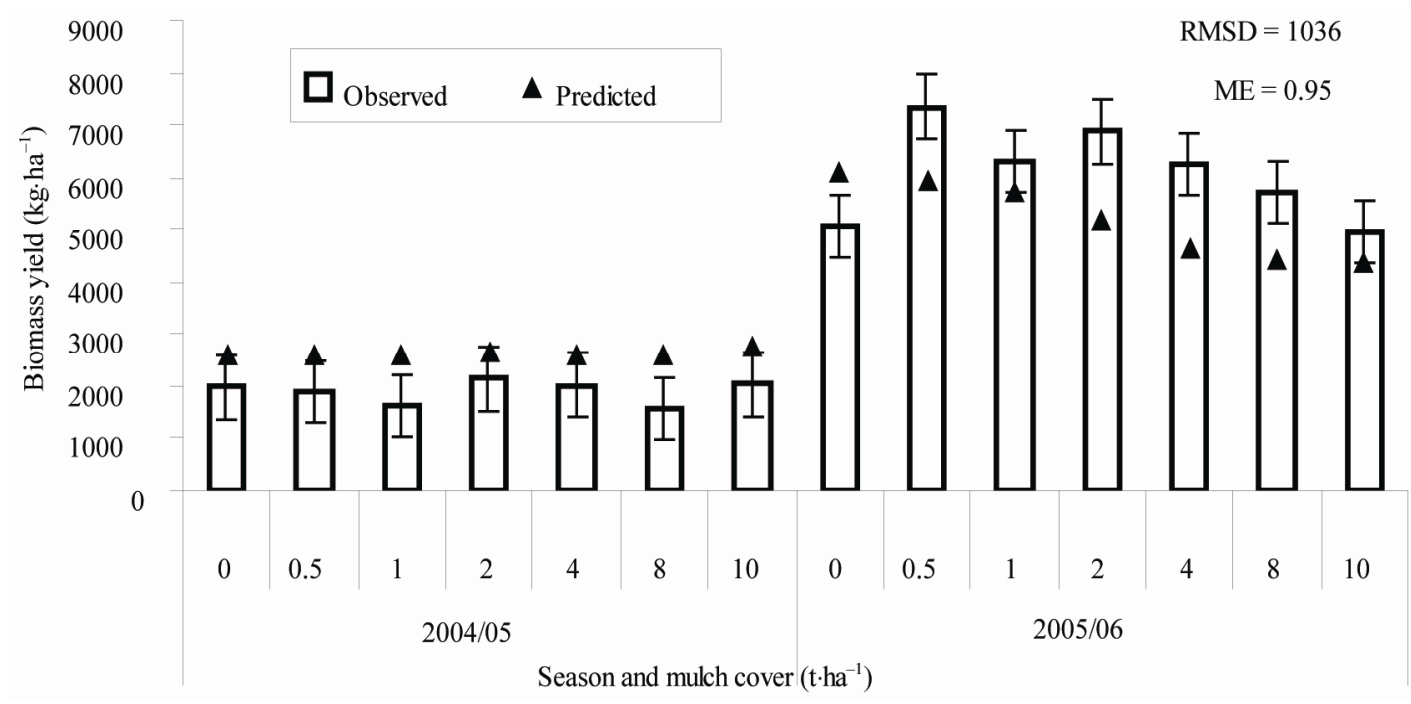

Figure 4. Observed and predicted total biomass yields for different mulch levels on a sand soil over two growing seasons at Lucydale experimental site. Error bars stand for standard error of means for the different mulch levels in each season across three replications.

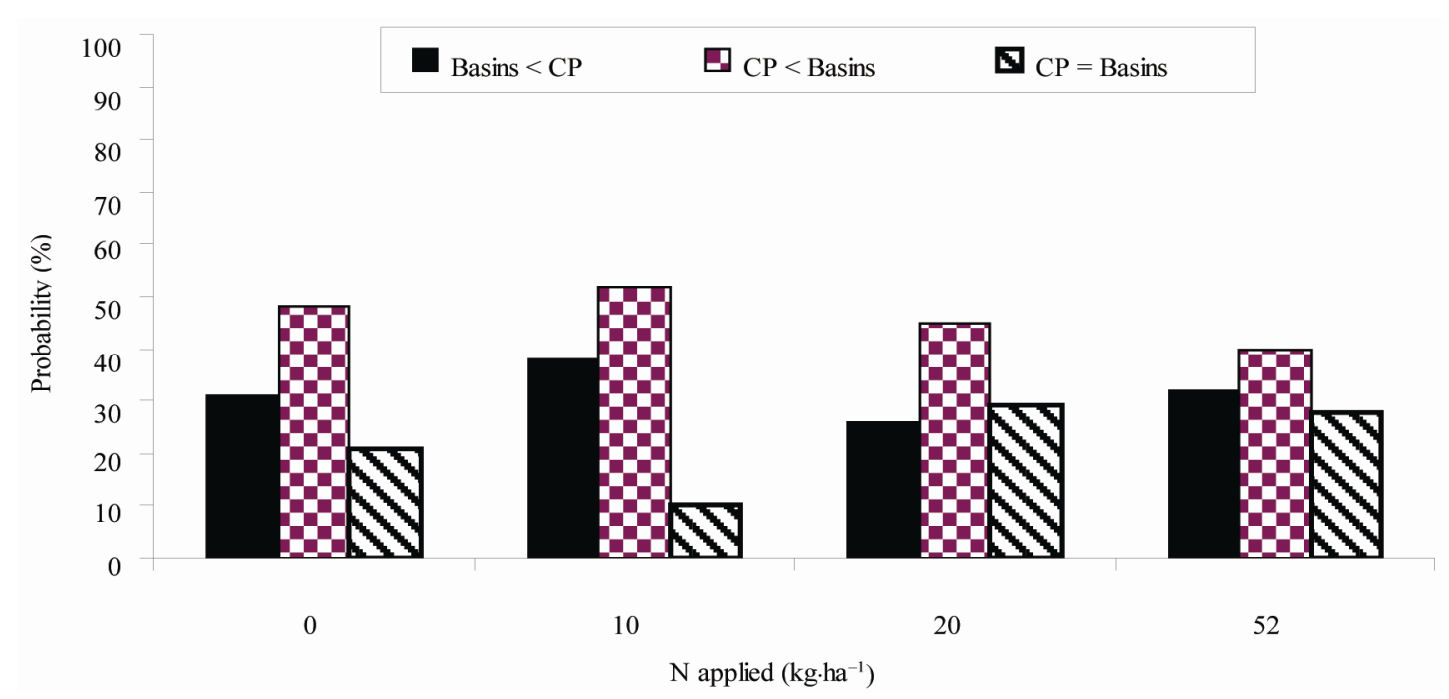

Figure 5. Probability of getting maize grain yield under two tillage systems (conventional ploughing and planting basins) and four $\mathrm{N}$ application rates $\left(0.10,20\right.$ and $\left.52 \mathrm{~kg} \cdot \mathrm{N} \cdot \mathrm{ha} \mathrm{g}^{-1}\right)$ over a 69 year period on a sandy soil under semi-arid conditions.

The chances of getting similar maize yields from the conventional and basin tillage systems increase at $\mathrm{N}$ application levels greater than the microdosing rate (10 $\left.\mathrm{kg} \cdot \mathrm{N} \cdot \mathrm{ha}^{-1}\right)$.

\section{CONCLUSIONS}

The APSIM model was used in this study to predict the observed crop yield and give a long term impact of the planting basin system and $\mathrm{N}$ fertilizer on maize yield. For most of the seasons there was reasonable agreement between observed and predicted maize yield data sets for the Matopos (clay soil) and Lucydale (sandy soil) ex- perimental sites. Maize yield under $4-10 \mathrm{t} \cdot \mathrm{ha}^{-1}$ mulch treatments could be suppressed in relatively wet seasons as result of inadequate $\mathrm{N}$ supply. This suggests that more $\mathrm{N}$ has to be applied in growing seasons with above average rainfall. Smallholder farmers need to get the seasonal climate forecasts well in time so that they can acquire adequate inorganic fertilizer for the wetter seasons. Long term simulations showed that maize productivity in both the conventional and planting basin tillage systems under semi-arid conditions can be improved substantially through addition of $\mathrm{N}$. The predicted maize yield indicated that $0,10,20$ and $52 \mathrm{~kg} \cdot \mathrm{N} \cdot \mathrm{ha}^{-1}$ give no 
significant yield differences below $1250 \mathrm{~kg} \cdot \mathrm{ha}^{-1}$ regardless of the tillage system used under these semi-arid conditions. The use of $10 \mathrm{~kg} \cdot \mathrm{N} \cdot \mathrm{ha}^{-1}$ is more favourable in both the conventional and planting basin tillage systems under semi-arid conditions because there are better chances of getting grain yield with the use of 10 $\mathrm{kg} \cdot \mathrm{N} \cdot \mathrm{ha}^{-1}$ in both tillage systems. It is less risky to use 10,20 and $52 \mathrm{~kg} \cdot \mathrm{N} \cdot \mathrm{ha}^{-1}$ in the planting basin system than the conventional system under the semi-arid conditions of southern Zimbabwe.

\section{ACKNOWLEDGEMENTS}

This paper is a contribution to WaterNet Challenge Program Project 17 'Integrated Water Resource Management for Improved Rural Livelihoods: Managing risk, mitigating drought and improving water productivity in the water scarce Limpopo Basin.

\section{REFERENCES}

[1] Rockström, J., Kaumbutho, P., Mwalley, J., Nzabi, A.W., Temesgen, M., Mawenya, L., Barron, J., Mutua, J. and Damgaard-Larsen, S. (2008) Conservation farming strategies in East and Southern Africa: Yields and rain water productivity from on-farm action research. Soil and Tillage Research, 103, 23-32.

[2] Nyagumbo, I. (2007) A review of experiences and developments towards conservation agriculture and related systems in Zimbabwe. In: Goddard, T., Zoebisch, M., Gan, Y., Ellis, W., Watson, A. and Somatpanit, S., Eds., No-Till Farming Systems. Special Publication Number 3, World Association of Soil and Water Conservation, 345-372.

[3] Twomlow, S., Hove, L., Mupangwa, W., Masikati, P. and Mashingaidze, N. (2008a) Precision conservation agriculture for vulnerable farmers in low potential zones. Papers Presented at the Challenge Program on Water and Food Theme 1 Rainfed Topic Workshop, Tamale, 22-25 September.

[4] Mupangwa, W., Twomlow, S. and Walker, S. (2008) The influence of conservation tillage methods on soil water regimes in semi-arid southern Zimbabwe. Physics and Chemistry of the Earth, 33, 762-767.

[5] Mupangwa, W., Twomlow, S., Walker, S. and Hove, L. (2007) Effect of minimum tillage and mulching on maize (Zea mays L.) yield and water content of clayey and sandy soils. Physics and Chemistry of the Earth, 32, 1127-1134.

[6] Keating, B.A., Carberry, P., Hammer, G.L., Probert, M.E., Robertson, M.J., Holzworth, D., Huth, N.I., Hargreaves, J.N.G., Meinke, H., Hochman, Z., McLean, G., Verbur, K., Snow, V., Dimes, J., Silburn, M., Wang, E., Brown, S., Bristow, K.L., Asseng, S., Chapman, S., McCown, R.L., Freebairn, D.M. and Smith, C.J. (2003) An overview of APSIM, a model designed for farming systems simulation. European Journal of Agronomy, 18, 267-288. doi:10.1016/S1161-0301(02)00108-9

[7] Delve, R.J. and Probert, M.E. (2004) Modeling nutrient management in tropical cropping systems. Australian
Centre for International Agricultural Research (ACIAR), Canberra, ACIAR Proceedings, No. 114.

[8] Shamudzarira, Z. and Robertson, M.J. (2002) Simulating the response of maize to nitrogen fertilizer in semi-arid Zimbabwe. Experimental Agriculture, 38, 79-96. doi:10.1017/S0014479702000170

[9] Dimes, J. and Malherbe, J. (2006) Climate variability and simulation modeling - challenges and opportunities. In: Mgonja, M.A., Waddington, S., Rollin, D., Masenya, M., Eds., Livelihoods in the Limpopo: CGIAR Challenge Program on Water and Food Project No. 1. Increased Food Security and Income in the Limpopo Basin through Integrated Crops, Soil Fertility and Water Management Options and Links to Markets, Proceedings of the CPWFPN 1 Inception Workshop, Polokwane, 25-27 January 2005.

[10] Ncube, B., Dimes, J.P., van Wijk, M., Twomlow, S. and Giller, K. (2009) Productivity and residual benefits of grain legumes to sorghum under semi-arid conditions in south-western Zimbabwe: Unravelling the effects of water and nitrogen using a simulation model. Field Crops Research, 110, 173-184. doi:10.1016/j.fcr.2008.08.001

[11] Moyo, M. (2001) Representative soil profiles of ICRISAT research sites. Chemistry and Soil Research Institute. Soils Report No. A666, AREX, Harare, Zimbabwe.

[12] Mupangwa, W. (2008) Water and nitrogen management for risk mitigation in semi-arid cropping systems. Ph.D Thesis (Unpublished), University of the Free State, South Africa.

[13] FAO (1998) World reference base for soil resources. World Soil Resources Report 84, Rome.

[14] Masikati, P. (2006) Tillage and manure interactions under dryland cropping in semi-arid Zimbabwe. Ph.M Thesis, Department of Soil Science and Agricultural Engineering, University of Zimbabwe, Zimbabwe.

[15] Rinaldi, M., Losavio, N. and Flagella, Z. (2003) Evaluation and application of CROPGRO-soybean model for improving soybean management under rainfed conditions. Agricultural Systems, 78, 17-30. doi:10.1016/S0308-521X(03)00030-1

[16] Mengel, K. and Kirkby, E.A. (1987) Principles of plant nutrition. 4th Edition. International Potash Institute, Worblaufen-Bern, Switzerland.

[17] Konig, H. and Varma, A. (2006) Intestinal Micro-organisms of termites and other invertebrates. Springer Publishers, Dordrecht.

[18] Nhamo, N. (2007) The contribution of different fauna communities to improved soil health: A case of Zimbabwean soils under conservation agriculture. Ph.D. Thesis, University of Bonn.

[19] Heal, O.W., Anderson, J.M. and Swift, M.J. (1997) Plant litter quality and decomposition: A historical overview. In: Cadisch, G. and Giller, K., Eds., Driven by Nature: Plant Litter Quality and Decomposition, CAB Publishing, Wallingford, 3-30.

[20] Twomlow, S., Rohrbach, D., Dimes, J., Rusike, J., Mupangwa, W., Ncube, B., Hove, L., Moyo, M., Mashingaidze, N. and Maphosa, P. (2008b) Micro-dosing as a pathway to Africa's Green Revolution: Evidence from broad-scale on-farm trials. Nutrient Cycling in Agroecosystems, 88, 3-15. doi:10.1007/s10705-008-9200-4 